\title{
Going stolon
}

\section{Deboleena Roy: Molecular Feminisms: Biology, Becomings, and Life in the Lab, University of Washington Press, Seattle, WA, 2018}

\section{Paula-Irene Villa ${ }^{1}$}

The aim of the new book from Deboleena Roy, feminist biologist and STS scholar working from a de-/postcolonial angle—or as she self-identifies: a "cyborg" (following Haraway), a "marginalized-knower-feminist-scientist and hyphenated creature" (p. 142 and 156) -is the reconciliation of several research and political fields: feminist activism, (molecular and synthetic) biology, and critical Science and Technology Studies (STS). The book's main argument is that this reconciliation can be achieved through a unifying, yet context-specific "molecular" approach. Thus, vast parts of the book are dedicated to arguing what precisely such an approach may mean and what it may be like, how it is different from the "molar" way of doing theory, activism, and research, while also describing how the author herself came to her perspectives through a variety of personal, political and professional experiences. While it is in fact rather interesting to read about the author's endeavors as a graduate student in molecular biology, and while these shared experiences make for a lively reading, the accounts also remain particular, difficult to share from a certain distance. As a gender studies scholar myself, situated within the German context, working on the intersection of social and cultural science, and with some standing in STS, many accounts of e.g. 'feminist' debates seem rather odd. I find it difficult to imagine how, for example, the question of whether "feminists should clone" could generate such extremely shocked, then even hostile reactions as Roy describes (p. 129). For many feminist articulations, especially in literature and media, have found technologically assisted reproduction a promising path. In addition, cloning might only be even known of in academic contexts. The dismay Roy encountered is even more surprising given that, as she herself explains later on, much of the feminist imaginary has evolved around the emancipatory options emerging from

Paula-Irene Villa

paula.villa@1mu.de

1 LMU Munich, Munich, Germany 
the disassociation of reproduction and sexuality/desire, including in vitro and other technically aided alternatives to hegemonic heterosexual intercourse.

Despite such perhaps highly specific positionings, the concrete and lively starting points of personal- and also professional-as-political experiences do enrich the book. Almost every chapter evolves around one or the other biographically framed attempts to make feminist sense of Roy's "nitty-gritty" work on the lab-bench (a rather repetitive phrasing throughout the book) and vice versa, of making sense of her scientific work in feminist contexts, along with others, and the resulting experiences of estrangement, debate, mistrust as much as of new forms of shared activism and knowledge. In this light, the book is a must-read for all scholars and researchers in the fields of gender and science and technology studies with feminist or otherwise critical ambitions, not only those who are particularly interested-let alone, experts - in (molecular) biology. It is also highly relevant to those professionals in the so called life-sciences who struggle with making sense of 'life' and how it matters.

The book is especially interesting for all those of us working either implicitly with or explicitly about the "matter of difference(s)" in regard to sex and gender. One cannot but agree, and I do so with much enthusiasm, with Roy's guiding epistemological plea for a sound and nuanced return to "matter" within gender studies. Of course, Roy is by no means the first or only scholar to formulate such a call; knowing this, Roy's invocation is rooted in contemporary scholarly work and debates. Her framing is clearly set by two main, widely overlapping strands of thought and work: First, and clearly most important, is her use of the 'rhizomatic' thinking of Deleuze and Guattari, although Roy also considers feminist thinkers who draw on their work to develop their own perspectives, especially Elisabeth Grosz and Rosi Braidotti. Second, Roy's own approach is firmly rooted in what has become canonized as 'new materialism', including not only those working under that rather umbrella-ish term such as Karen Barad and Ines van der Tuin (and, as mentioned, Grosz and Braidotti), but also a much wider array of feminist STS, from Donna Haraway to Evelyn Fox-Keller to Vicki Kirby, and many others. Deeply imbedded in these perspectives, Roy's own approach to science, and her concrete practice as a biologist, are guided by the will to generate a (in my words) post-post-structuralist position or (in Roy's own words) a "reciprocal ontology" (p. 69). What does this mean, and how does it materialize? In short: it seems to mean an immensely normative paradigm, guided by a specific ethics of 'conviviality' - and then materialized in a set of concrete "molecular" techniques, of activism, intellectual endeavor, and research. The paradigmatic example of a molecular, reciprocal way of living in the world and of mattering is the stolon-a particular grass.

In five subsequent chapters, Roy develops different dimensions of her "molecular" project. Each chapter starts from and revolves around either a specific politically motivated or scientific-technological issue, seeking to not only combine both dimensions - the political and the scientific_-but much more, i.e. to show and develop their mutual co-constitution. The chapters deal with, for example, cloning and the question of whether it can be a feminist practice; or, elsewhere, with bacterial recombination and genetic engineering as ethical and political phenomena to perhaps be learnt from by feminists and STS scholars alike. All of the chapters are 
wonderfully written, and clearly structured. They can be read as single contributions (as some were individually published previously), each being a self-sufficient piece including conceptual and theoretical arguments and empirical insights. If read at a stretch, however, the reading experience is partly repetitive, being sometimes redundant on what I call the programmatic dimension: The book too often formulates its or, rather, the authors' intentions, the central aim or plea, its politico-epistemological stance and program. Thus, not only do the same authors and concepts appear again and again - always undoubtedly making sense-but, and more crucially so, the book repeats the same normative promises time after time. Although concrete experimental techniques or biological issues are mentioned right from the beginning, it actually takes over 63 pages until the first concrete, science-related examples are presented and discussed in more detail, and until the envisioned alternatives to traditional perspectives are actually laid out "on the lab-bench" of a "busy bench scientist" (as Roy describes herself, p. 12). Otherwise, the text contains perhaps too much wishful thinking, albeit in the best sense of the literal word. It asks: what would a better, more ethically conscious and empirically sustainable thinking be like, ideally? The general answer is marked by a desire for "reciprocal ontology" (p. 69), an "ethics of encounter" (p. 58), by "molecular" approaches that cherish fluidity, changefulness, or "becomings," and that refuse prior-to-practice categorization or identity politics (as the latter wrongly, I think, associated by Roy with "molar" projects such as 'women in STEM' approaches). Roy aims at a pluralist, stolonic, post-humanist ethics of matter (p. 58). This is in itself at least interesting, actually it is inspiring, instructive, and resonates with several crucial debates in social sciences. But as an informed yet not fully familiar reader, I would have wished for the text to walk me through the concretization of such a program more often and in more detail than to read yet another half-chapter outlining the normativity of the program itself.

Heavily and repeatedly drawing on the philosophical ideas formulated by Deleuze and Guattari as well as on the work of Grosz and Braidotti, Roy argues that "molecular projects" in science (especially biology), and in activism (especially in postand decolonial feminism), share an openness towards changefulness and becoming as a shared post-essentialist ontology. Such an ontology is not-and, according to Roy, should not be-limited to specific areas of politics or research nor to particular forms of living beings, but is, as the book argues, a dimension of virtually any matter, be it (in conventional words) organic, human, living or of any other sort. In other words: Roy's approach is guided by the notion that "all matter is changeful" and thus by the will to not find, but to rather develop conceptual, political and practical scientific procedures based on such changefulness-as opposed to the established, perhaps hegemonic politics, concepts, and procedures that she labels "molar". The latter would be approaches relying on identifiable pre-given or pre-settled ontological entities. Roy presents some examples of "molar" approaches; some, such as the formerly widely used dualism of sex/gender or the 'Women in STEM' approaches are more, others, such as strands of second wave feminism which Roy identifies as 'identity based', perhaps less convincing in their description and evaluation.

The notion of "biopossibilities" (p. 5) is crucial to the book, entailing the respectful and curious, not colonizing acknowledgment that all actants, objects and subjects, life-forms and other perhaps not-even-yet-fully-known forms, all have a 
capacity to act, to practices and knowings in their own right. One paradigmatic example of how this is put into conceptual and practical work, is that of "stolons": These are "creeping grasses" (p. 5) spread by "stolonic processes of developing new shoots and extending horizontal stems that grow above ground" (idem). Such grasses "reach out", make connections, "feel around", and extend; they "sense, interpret, and respond to environmental signals" (p. 61). Roy takes stolons as a guiding example for her own approach precisely because of the qualities she sees in their way of being. She, too, seeks to develop a caring and curious feeling for matter-be it bacteria or molecular modeling or any other-and a mutual, respectful inter-intra-action (to build on Karen Barad's terminology) between all actants, in the lab or elsewhere. Roy seeks to connect not only institutionally pre-assembled elements, such as Petri dishes, bacteria, and subcloning kits in the lab, but also unlikely, disparate, socially separate issues, practices, and entities, such as childhood memories, visual patterns in art, and movie heroes. Indeed, Roy describes her own intellectual trajectory, in these terms, as "stolonic" (p. 71). Despite the suggestive and eloquent rhetoric of the book - it is really extremely well written - it often remains unclear how and why certain elements are connected, following which criteria, and how this precisely effects the concrete work in the lab. And albeit stressing her wish to critically dismantle conceptual or empirical binaries as such—such as male/female, sex/gender, discourse/matter and many more-and despite stressing once and again along the book that both molar and molecular approaches are relevant and useful, depending on the context and issue at stake, Roy does make it very clear that 'molecular' approaches are better and more useful in any possible sense: they are empirically more sound since they better acknowledge the complexity and dynamics of any matter, and they respect far better than other-molar - approaches the unclear, shifting, construed ontology of subjects, objects, and practices. Thus, molecular approaches seem far better fit for an "ethics of encounter" which seeks to be 'all-inclusive' (my wording). While this is in itself an interesting take, and one which resonates with all social constructivist approaches, old and new school, in social sciences, the details are not always as convincing.

To be fair, several chapters do contain concrete analysis and accounts of how this normative program is set to work. Chapter 3 for example, on "bacterial sex" and genetic mixing processes beyond reproduction, is a delightful and insightful read, an eye-opener on how to "reframe sex" (p. 107) and on how to approach bacterial "coding" as a language in its own right, even as a poetic practice which escapes mechanistic or profitable exploitation. Similarly, chapter 4 walks us through the sensitive issue of human (sub-)cloning, passing through important details of synthetic biology and its modus of "playful proliferation of difference" (p. 133). By appropriating the step-by-step process of subcloning, paying special caring attention to the cells as competent actants in their own right (p. 137), Roy develops a feminist, post/decolonial scientific practical perspective. Despite a rather uncritical, even enthusiastic embracing of differences, there is much to be learnt and enjoyed through the lively accounts of concrete intellectual-political-scientific practices presented by Roy in this chapter especially. As a sociologist, I'd love to discuss the semantic and material affinity of neoliberal politics and markets-on which differences are welcomed and profitable assets-with molecular perspectives. 
More generally, the book adds to important ongoing debates not only on particular biopolitical issues such as cloning, genetic engineering or reproductive technologies, but to a much broader and fundamental aspect of all life. Care, understood as the response towards the needs of any living matter, is currently a huge issue, weaving together various social movements (ecological, feminist, decolonial, antiviolence and protesting austerity), as well social and academic critique of toxic capitalism, and is having an immense effect on social policies as well as the mundane of everyday life. Care is the fundamental problematic of our times, and it raises fundamental questions regarding the ethics and politics of conviviality. Roy's molecular approach towards matter with its focus on an "ethics of encounter" speaks precisely to this conversation on care, and has much to offer.

Acknowledgements Open Access funding provided by Projekt DEAL.

Open Access This article is licensed under a Creative Commons Attribution 4.0 International License, which permits use, sharing, adaptation, distribution and reproduction in any medium or format, as long as you give appropriate credit to the original author(s) and the source, provide a link to the Creative Commons licence, and indicate if changes were made. The images or other third party material in this article are included in the article's Creative Commons licence, unless indicated otherwise in a credit line to the material. If material is not included in the article's Creative Commons licence and your intended use is not permitted by statutory regulation or exceeds the permitted use, you will need to obtain permission directly from the copyright holder. To view a copy of this licence, visit http://creativecommons.org/licen ses/by/4.0/.

Publisher's Note Springer Nature remains neutral with regard to jurisdictional claims in published mapsand institutional affiliations.

Paula-Irene Villa is full professor and chair for Sociology and Gender Studies at Munich University (LMU). Her research and teaching focuses on gender and social theory, and in empirical projects mainly on biopolitical issues, such as cosmetic surgery or fitness practices; care in contemporary societies, popular culture, and on gender in political mobilizations. www.gender.soziologie.uni-muenchen.de. 